\section{Institution of Electrical Engineers Awards}

THE Council of the Institution of Electrical Engineers has made the following awards of premiums for papers read during the session 1941-42, or accepted for publication: Institution Premium to Mr.J.M. Meek; Ayrton Premium to Mr.J.S. Forrest ; Fahie Premium to Dr. W. G. Radley and Mr. E. P. G. Wright; John Hopkinson Premium to Dr. A. L. Williams and Mr. L. E. Thompson; Kelvin Premium to Mr. E. Colin Cherry; Overseas Premium to Prof. K. Aston and Mr. M. V. Kesava Rao ; Extra Premiums to Dr. A. H. M. Arnold, Mr. G. W. Bowdler, Messrs. G. W. Bowdler and W. G. Standring, Mr. R. Davis, Dr. H. D. Einhorn and Prof. B. L. Goodlet, Dr. Hackett and Mr. A. M. Thomas, Mr. E. A. Richards, Mr. V. Sia, Messrs. R. C. Woods and A. S. MacDonald; Installations Section Premiums to Messrs. L. J. Davies, H. R. Ruff and W. J. Scott (Crompton Premium), Mr. R. Grierson; Meter and Instrument Section Premiums to Messrs. E. A. Burton, J. S. Forrest and T. R. Warren (Silvanus Thompson Premium), Mr. D. J. Bolton; Transmission Section Premiums to Mr. J. W. Leach (Sebastian de Ferranti Premium), Messrs. W. Casson and F. H. Birch; Wireless Section Premiums to $\mathrm{Mr}$. O. S. Puckle (Duddell Premium), Dr. D. C. Espley and Mr. D. O. Walter (Ambrose Fleming Premium), Messrs. J. E. Thwaites and F. J. M. Laver.

\section{Earthquake in Ecuador}

REPORTS have been received from Guayaquil, the chief port of Ecuador, that a severe earthquake took place in the interior on the night of May 13-14. Guayaquil itself was severely shaken for some 60 seconds according to human perception, and buildings collapsed. It is estimated that about sixty people lost their lives. Mr. J. J. Shaw's seismograph at West Bromwich recorded a severe earthquake at 2h. $25 \mathrm{~m}$. 52s. U.T. on May 14. Further news is awaited. It will be recalled (NATURE, Feb. 11, 1939, p. 238) that several earthquakes shook a considerable area in Ecuador including the towns of Vallechillos and Quito on the night of February 1, 1939. On that occasion the volcano Cotopaxi erupted.

\section{Earthquakes Registered at Kew}

Two strong distant earthquakes have recently been recorded at Kew Observatory. The first, on April 8, 1942, began recording on the vertical component at $15 \mathrm{~h} .53 \mathrm{~m}$. 58s. U.T. impulsively, and on the $\mathrm{N}$ and $\mathrm{E}$ components at the same time $P$ was emergent. The shock probably originated some $11,000 \mathrm{~km}$. distant, at maximum attained an amplitude of $410 \mu$ at Kew, and finished recording at 19h. 20m. U.T. The second, on April 13, began recording impulsively on all three components at $07 \mathrm{~h} .55 \mathrm{~m}$. $48 \mathrm{~s}$. U.T. from an epicentral distance of $6,130 \mathrm{~km}$., attained a maximum amplitude of $94 \mu$ and finished recording at $10 \mathrm{~h} .00 \mathrm{~m}$. U.T. All readings are tentative.

Between April 15 and May 5 eighteen earthquakes were registered by the seismographs at Kew Observatory. All these shocks gave rise to small amplitudes with the exception of the earthquake of April 20. This began recording at $08 \mathrm{~h} .52 \mathrm{~m} .40 \mathrm{~s}$. U.T. and finished recording at $10 \mathrm{~h}$. 25m. U.T. The interpretation of this record is at present tentative, though an epicentral distance of $125^{\circ}$ is possible.

\section{The Ipswich Man}

THE skeletal remains known as the Ipswich man, which have been housed at the Royal College of Surgeons, London, since they were discovered in Bolton and Co's brickfield, Ipswich, in 1911, have now, through the instrumentality of Mr. Reid Moir, and the kindness of the president and Council of the College, been presented to the Ipswich Museum. Since 1911 a great deal has been discovered regarding the age of these remains, which were thought originally to be older than the Upper Chalky Boulder Clay-a deposit of one of the major glaciations of East Anglia. It now seems clear that the skeleton is referable to one of the prehistoric floors situated in the slopes of the adjacent valley, and examples of flint implements, etc., found in these floors are exhibited with the human bones in the entrance hall of the Ipswich Museum. Though all the geological and archæological aspects of this matter are not yet completely understood, it is highly probable that the Ipswich man lived in the earlier part of Upper Palæolithic times, and is of considerable antiquity.

\section{Announcements}

Prof. E. H. Alton, registrar and professor of classics in Trinity College, Dublin, who represented the College in the Dail from 1923 until 1937, when the University representation was abolished and he was elected to the. Irish Senate, has been appointed provost of the College in succession to the late Dr. W. E. Thrift.

Mr. Harry Brearley, the well-known steelmaker of Sheffield, has been elected to honorary member. ship of the Iron and Steel Institute. Mr. Brearley's recently published autobiography was reviewed in NATURE of April 11, p. 397.

The British Standards Institution has been recognized by the Government as the sole organization for the issue, in consultation with any Government, professional or industrial bodies concerned, of standards having a national application. In regard to the preparation and issue of codes of practice for building and civil engineering work, the Minister of Works and Buildings is making special arrangements by the appointment of a representative committee with which the Institution is co-operating.

As from the commencement of next session, the name of the Meter and Instrument Section of the Institution of Electrical Engineers will be altered to "Measurements Section". The Section will include within its scope all matters relating to electrical measurement and control, the design and application of the apparatus, and the materials employed in connexion with them.

A Discussion on "Soviet Metallurgy", arranged by the Faculty of Science, Marx House, will be held at the London School of Hygiene and Tropical Medicine, Keppel Street, W.C.1, on May 28 at 7 p.m. The discussion will be based on a paper by Mr. Tom Barker, who took a leading part in the creation of the great Kuzbas Metallurgical Combine in Siberia. Tickets of admission, including a copy of Mr. Barker's paper, can be obtained from Marx House, Clerkenwell Green, London, E.C.1, price $2 s$. 